14. Skliar, G.P., and I.V. Fysun "Insurance and reinsurance of risks of green tourism entities as a necessary condition for its development." Scientific Bulletin of Poltava University of Economics and Trade. Ser. : Economic sciences, no.4, 2012, pp. 251-257.

15. "Insurance and pandemic. What should insurers and reinsurers think about?" Insurance TOP, no.2 (70), 2020, pp. 4-5, forinsurer.com/files/file00677.pdf. Accessed 9 Nov. 2020.

16. Suprun, A.A. "Introduction of insurance of tourist, hotel and restaurant business as a factor of increase of financial reliability of insurance companies." Bulletin of the Kryvyi Rih Economic Institute of the Kyiv National University, no. 2, 2013, pp. 79-85.

17. Chvertko, L.A., and T.A.Demchenko "Insurance of tourist risks: problems of theory and practice." Economic horizons, no. 1 (4), 2018, pp. 67-75.

18. Melnychuk, Yu. M., Shkolenko, O.B., Vinnytska, O.A., and T. O. Korniienko. "Features of the assessment of the financial condition of life insurance companies in an independent region: priorities for insurance business and clients." Financial and credit activity: problems of theory and practice, issue 1 , no. 32, 2020, pp. 147-157.

19. Melnychuk, Yu., Chvertko, L. A., Korniienko, T. A., Vinnytska, O. A., and O. V. Garmatiuk "Analysis of the factors influencing the market of insurance services in life insurance." TEM Journal, vol.8, Is.1, 2019, pp. 201-206.

УДК 336.717.3

doi: 10.15330/apred.1.16.67-74

\title{
РОЗВИТОК БАНКІВСЬКОГО СЕКТОРУ УКРАЇНИ В УМОВАХ КОНКУРЕНТНОЇ ІНТЕРНАЛІЗАЦЇ: МЕТОДИЧНИЙ ПІДХД ДО ОЦІНЮВАННЯ
}

Дятлова Ю.В.

\author{
Донецький державний університет управління, \\ Міністерство освіти і науки України, \\ кафедра фінансів та обліку, \\ вул. Карпінського, 58, Маріуполь, \\ 87513, Україна, \\ тел.: 0500471466, \\ e-mail: yuliyadyatlova25@gmail.com
}

\begin{abstract}
Анотація. Сучасний розвиток банківського сектору України відбувається в умовах жорсткої конкуренції вітчизняних банків з іноземними банками, які активно використовують інструменти інтерналізації як конкурентні переваги на українському фінансовому ринку. Актуальність дослідження таких умов розвитку банківського сектору та необхідність розроблення методичного підходу до їх оцінювання зумовили мету даної статті. У дослідженні використано методи статистичного аналізу (для визначення тенденцій розвитку банківського сектору за певними показниками); математичного моделювання і розрахунковий (для визначення рівня конкурентної інтерналізації та інших показників), логічного узагальнення (для формулювання результатів і висновків).

Встановлено, що показники кількості присутніх на національному ринку іноземних банків та їх активів є недостатніми для характеристики умов розвитку вітчизняних банків. Запропоновано використовувати коефіцієнт конкурентної інтерналізації. Удосконалено методичний підхід до оцінювання розвитку банківського сектору в умовах конкурентної інтерналізації із застосуванням сукупності статичних i динамічних індикаторів, які використовуються в комплексі або як окремі та визначаються для країни відносно іншої країни або іiі банку за рік або інший період. Розрахунками доведено, що за станом впливу іноземних банків банківський сектор України може бути порівняний з країн Співдружності незалежних держав з банківським сектором Молдови, з країн-членів Свропейського Союзу - з банківським
\end{abstract}


сектором Словенії. Використання показників на практиці дасть можливість формувати інформаційно-статистичний ресурс щодо рівня розвитку банківського сектору, зокрема банків 3 вітчизняним капіталом, а також приймати рішення щодо інтеграції банківського сектору до інших країн.

Ключові слова: банківський сектор, розвиток, конкурентна інтерналізація, оцінювання, методичний підхід, показники, тенденції.

\title{
DEVELOPMENT OF THE BANKING SECTOR OF UKRAINE IN THE CONDITIONS OF COMPETITIVE INTERNALIZATION: METHODICAL APPROACH TO EVALUATION
}

\author{
Donetsk State University of Management, \\ Ministry of Education and Science of Ukraine, \\ Department of Finance and Accounting, \\ Karpinskoho str., 58, Mariupol, \\ 87513, Ukraine, \\ tel.: 0500471466, \\ e-mail: yuliyadyatlova25@gmail.com
}

Diatlova Yu.V.

\begin{abstract}
The modern development of the banking sector of Ukraine takes place in conditions of fierce competition of domestic banks with foreign banks, which actively use internalization tools as a competitive advantage in the Ukrainian financial market. The relevance of the study of such conditions for the development of the banking sector and the need to develop a methodical approach to their evaluation determined the purpose of this article. The research were used methods of statistical analysis (to determine trends in the development of the banking sector by certain indicators), mathematical modeling and calculation (to determine the level of competitive internalization and other indicators), logical generalization (to formulate results and conclusions).

It was found that the indicators of the number of foreign banks present on the national market and their assets are insufficient to characterize the conditions of development of domestic banks. It was proposed to use the coefficient of competitive internalization. The methodical approach to assessing the development of the banking sector in a competitive internalization was improved using a set of static and dynamic indicators, which are used in combination or as separate and are determined for a country relative to another country or its bank for a year or other period. Calculations have shown that the influence of foreign banks on the banking sector of Ukraine can be compared with the banking sector of Moldova from the countries of the Commonwealth of Independent States, from the European Union member states - with the banking sector of Slovenia. The use of indicators in practice will allow forming information and statistical resource on the level of the banking sector development, in particular of banks with domestic capital, as well as to make decisions on the integration of the banking sector to other countries.
\end{abstract}

Keywords: banking sector, development, competitive internalization, evaluation, methodical approach, indicators, tendencies.

Вступ. Економічний розвиток будь-якої держави неможливий без розвинутої та ефективно функціонуючої фінансової системи. На сучасному етапі фінансова система України $\epsilon$ банкоцентричною, тому розвиток банківського сектору, завдяки функціонуванню якого реалізуються зв'язки між усіма економічними суб'єктами, є пріоритетним.

Для сучасного розвитку банківського сектору характерними є процеси глобалізації й інтеграції, зокрема такі їх прояви, як інтернаціоналізація та інтерналізація, що підсилюють конкуренцію на фінансовому ринку. Процеси інтернаціоналізації, пов'язані 3 діяльністю іноземних банків у банківському секторі, існують майже у кожній країні і відрізняються від тих, що характеризують діяльність банків з національним капіталом. Тому, на нашу 
думку, слід розрізняти процеси, пов'язані з функціонуванням представництв та філій іноземних банків на ринку банківських послуг окремої країни або групи країн, а також іноземного інвестування в активи (інтернаціоналізація), від таких, що характеризують діяльність банків певної країни у рамках іï національного банківського сектору чи системи під впливом присутності іноземних банківських установ та іноземних активів у вітчизняних банках [1].

Присутність в банківському секторі приймаючих країн іноземних банків з акцентом на створенні умов конкуренції та перевагах досліджували зарубіжні вчені, зокрема G. Clarke, R. Cull, M. Soledad, M. Peria, S. Sánchez [2], S. Claessens [3], щодо проблем, пов'язаних з міжнародною діяльністю банків, та підходів до їх вирішення - S. Chava, A. Purnanandam [4], T. Levitt [5]. Вплив присутності іноземних банків у національному банківському секторі досліджували вітчизняні вчені, такі як В. Геєць [6], О. Дзюблюк [7], Г. Карчева [8] та ін., зокрема щодо позитивних і негативних наслідків для розвитку банківського сектору та конкурентоспроможності вітчизняних банків. Для оцінювання розвитку сектору використовувалися загальноприйняті в банківській практиці показники. В міжнародній практиці присутність іноземного капіталу аналізується за показниками частки іноземних банків у загальній їх чисельності та в загальному обсязі активів. Питання спеціалізованої методики та показників у науковій літературі достатньо не опрацьовані. Між тим, вченими звертається увага на необхідність використання бізнес-аналітики в банківській сфері [9]. Тому напрацювання щодо означеного питання $\epsilon$ актуальними і своєчасними.

Постановка завдання. Метою статті є удосконалення методичного підходу до оцінювання розвитку банківського сектору України в умовах конкурентної інтерналізації.

Результати дослідження. Відкриття фінансового ринку України для міжнародних банків призвело до певного пригнічення розвитку національних гравців, оскільки сформувалася ситуація, коли перші активно використовують інструменти інтерналізації як переваги у конкуренції на українському ринку, другі стикаються 3 необхідністю конкурувати з більш потужними за фінансовою спроможністю і набором банківських продуктів суб'єктами і виконувати жорсткі вимоги щодо обачності, а банківська система в цілому стикається із загрозою втрати фінансової безпеки.

Так, у останні роки спостерігається значне масштабування явища впливу банків іноземних банківських груп на розвиток банківського сектору України, а саме збільшенням їх кількості (табл. 1), а також активів.

Так, протягом 2008-2019 років чисельність банків у вітчизняному банківському секторі зменшилася в 2,5 рази, при цьому кількість банків 3 іноземним капіталом зменшилася значно менше - в 1,5 рази, а банків зі 100\% іноземним капіталом збільшилася у 1,4 рази. На початок 2020 року налічується 35 банків 3 частково іноземним та зі 100\%-ним іноземним капіталом з 75 наявних. А зростання кількості банків зі 100\%-ним іноземним капіталом, що простежується в останні три роки, може привести до втрати незалежності фінансової системи України.

Національний банк України, при наведенні даних у Огляді банківського сектору, враховує як іноземні банки тільки ті, що зі 100\% капіталом. Такий підхід штучно збільшує чисельність вітчизняних банків (2018 рік - 51 банк, за фактом - 35). Крім того, банківська статистика не враховує активи іноземних банків. Між тим, у кризові роки іноземні банки виводили активи, і перш за все це були банки з частково іноземним капіталом. Це не може не вплинути на безпеку та фінансову стійкість банківського сектору. 
Кількість банків в Україні з 2007 по 2019 роки $^{1}$

Таблиия 1

The number of banks in Ukraine from 2007 to $2019^{1}$

\begin{tabular}{|l|c|c|c|c|c|c|}
\hline $\begin{array}{c}\text { Рік } \\
\text { на 01.01) }\end{array}$ & $\begin{array}{c}\text { Кількість } \\
\text { діючих } \\
\text { банків }\end{array}$ & $\begin{array}{c}\text { 3 них 3 } \\
\text { іноземним } \\
\text { капіталом }\end{array}$ & $\begin{array}{c}\text { Частка в } \\
\text { загальній } \\
\text { кількості, } \\
\text { \% }\end{array}$ & $\begin{array}{c}\text { У т.ч. зі } \\
100 \% \\
\text { iноземним } \\
\text { капіталом }\end{array}$ & $\begin{array}{c}\text { Частка в } \\
\text { загальній } \\
\text { кількості, } \\
\%\end{array}$ & $\begin{array}{c}\text { Частка в } \\
\text { кількості банків } \\
\text { 3 іноземним } \\
\text { капіталом, \% }\end{array}$ \\
\hline 2008 & 82 & 38 & 46,3 & 18 & 22,0 & 47,4 \\
\hline 2009 & 184 & 53 & 28,8 & 17 & 9,2 & 32,1 \\
\hline 2010 & 182 & 51 & 28,0 & 18 & 9,9 & 35,3 \\
\hline 2011 & 176 & 55 & 31,3 & 20 & 11,4 & 36,4 \\
\hline 2012 & 176 & 53 & 30,1 & 22 & 12,5 & 41,5 \\
\hline 2013 & 176 & 53 & 30,1 & 22 & 12,5 & 41,5 \\
\hline 2014 & 180 & 49 & 27,2 & 19 & 10,6 & 38,8 \\
\hline 2015 & 163 & 51 & 31,3 & 19 & 11,7 & 37,3 \\
\hline 2016 & 117 & 41 & 35,0 & 17 & 14,5 & 41,5 \\
\hline 2017 & 96 & 38 & 39,6 & 17 & 17,7 & 44,7 \\
\hline 2018 & 82 & 38 & 46,3 & 18 & 22,0 & 47,4 \\
\hline 2019 & 77 & 37 & 48,1 & 23 & 29,9 & 62,2 \\
\hline 2020 & 75 & 35 & 46,7 & 23 & 30,7 & 65,7 \\
\hline
\end{tabular}

${ }^{1}$ Укладено за офіційними статистичними даними Міністерства фінансів України.

URL: https://index.minfin.com.ua/ua/banks/stat/count/2019.

Міжнародний валютний фонд і Світовий банк при дослідженні міжнародної банківської діяльності використовують такі показники присутності іноземних банків у банківському секторі приймаючої країни, як частка у загальній їх чисельності та в загальному обсязі активів. Саме ці показники покладено в основу компаративного аналізу по країнам, групам країн, регіонам і в світі загалом, який викладено у звітах міжнародних фінансових інституцій $[10 ; 11]$.

Аналіз сучасного стану та тенденцій розвитку банківського сектору потребує постійної уваги з огляду на стійку тенденцію щодо небезпечного рівня конкурентної інтерналізації, що проявляється в умовах, які не забезпечують розвиток вітчизняних банків. Конкурентну інтерналізацію слід розглядати як процес системних перетворень екстерналій на фінансовому ринку приймаючої країни під впливом конкуренції між іноземними банками або з іноземним капіталом та національними [12].

Для впливу на умови конкурентної інтерналізації, а також для урахування світових i регіональних тенденцій розвитку банківського сектору, необхідно застосовувати певні індикатори. 3 цією метою розроблено методичний підхід до оцінювання розвитку банківського сектору в умовах конкурентної інтерналізації, сутність якого полягає в застосуванні системи статичних і динамічних індикаторів (табл. 2), які можуть використовуватися в комплексі або як окремі та визначатися на певний рік або за період, що дасть можливість формувати інформаційно-статистичний pecypc, а на цих засадах визначати ефективні інструменти впливу на розвиток банків 3 вітчизняним капіталом. 


\section{Система індикаторів для оцінки розвитку банківського сектору} в умовах конкурентної інтерналізації

Table 2

The system of indicators for evaluation of the banking sector development in conditions of competitive internalization

\begin{tabular}{|c|c|}
\hline Назва індикатора & Формула для розрахунку \\
\hline  & $\begin{array}{l}I P A_{f b s}=A_{f b s} / A_{b s c} * 100, \\
\text { де } A_{f b s}-\text { активи банків з іноземним капіталом, грн.; } \\
A_{b s c}-\text { активи банківського сектору країни, грн. }\end{array}$ \\
\hline $\begin{array}{lrr}\text { 2. Індекс } & \text { присутності } \\
\text { іноземних } & \text { банків } \\
\text { банківському } & \text { секторі } \\
\text { країни за їх } & \text { кількістю } \\
\left(I P N_{f b s}\right) & & \end{array}$ & $\begin{array}{l}I P N_{f b s}=N_{f b s} / N_{b s c} * 100, \\
\text { де } N_{f b s}-\text { кількість банків з іноземним капіталом, од.; } \\
N_{b s c}-\text { кількість установ банківського сектору країни, од. }\end{array}$ \\
\hline $\begin{array}{l}\text { 3. Коефіцієнт } \\
\text { конкурентної інтерналізації } \\
(I C I)\end{array}$ & $\begin{array}{l}I C I=I P A_{f b s} / 100 * I P N_{f b s} / 100, \\
\text { де } I P A_{f b s}-\text { індекс присутності іноземних банків у } \\
\text { банківському секторі країни за їх активами, \%; } \\
I P N_{f b s}-\text { індекс присутності іноземних банків у } \\
\text { банківському секторі країни за їх кількістю, \%; }\end{array}$ \\
\hline $\begin{array}{lr}\text { 4. Індекс } & \text { присутності } \\
\text { іноземного } & \text { банку } \\
\text { банківському } & \text { секторі } \\
\text { країни за його } & \text { активами } \\
\left(I P A_{f b s 1}\right) & \end{array}$ & $\begin{array}{l}I P A_{f b s 1}=A_{f b s 1} / A_{b s c} * 100, \\
\text { де } A_{f b s 1}-\text { активи банку з іноземним капіталом, грн.; } \\
A_{b s c}-\text { активи банківського сектору країни, грн. }\end{array}$ \\
\hline $\begin{array}{lr}\text { 5. Розмір } & \text { групи } \\
\text { вітчизняних } & \text { банків } \\
\text { приватним } & \text { капіталом } \\
\text { банківському } & \text { секторі } \\
\text { країни }\left(R_{v b s}\right) & \\
\end{array}$ & $\begin{array}{l}R_{v b s}=K_{v b s} / K_{b s c} * 100, \\
\text { де } K_{v b s c}-\text { капітал вітчизняних банків } 3 \text { приватним } \\
\text { капіталом, грн.; } \\
K_{b s c}-\text { капітал банківського сектору країни, грн. }\end{array}$ \\
\hline \begin{tabular}{lrr} 
6. Розмір & \multicolumn{2}{c}{ банківського } \\
сектору країни & по \\
відношенню & до & іншої \\
країни $\left(R_{b s c 1}\right)$, & банку & іншої \\
країни $\left(R_{b s c 2}\right)$, &
\end{tabular} & $\begin{array}{l}R_{b s c 1}=K_{b s c} / K_{b s k} * 100, \quad R_{b s c 2}=K_{b s c} / K_{b k} * 100, \\
\text { де } K_{b s c}-\text { капітал банківського сектору країни, од. } \\
\text { валюти; } \\
K_{b s k}-\text { капітал банківського сектору іншої країни, од. } \\
\text { валюти; } \\
K_{b k}-\text { капітал банку іншої країни, од. валюти }\end{array}$ \\
\hline $\begin{array}{l}\text { 7. Індекс } \\
\text { банківського } \\
\text { країни }\left(I R_{b s c}\right)\end{array}$ & $\begin{array}{l}I R_{b s c}=A_{b s c(t)} / A_{b s c(t-1)} * 100, \\
\text { де } A_{b s c(t)}-\text { активи банківського сектору країни в період } \\
t, \text { грн.; } \\
A_{b s c(t-1)}-\text { активи банківського сектору країни в період } t- \\
1, \text { грн. }\end{array}$ \\
\hline $\begin{array}{lr}\text { 8. Індекс розвитку групи } \\
\text { вітчизняних } & \text { банків } 3 \\
\text { приватним } & \text { капіталом } \\
\text { банківського } & \text { сектору } \\
\text { країни }\left(I R_{b s c 1}\right) & \end{array}$ & $\begin{array}{l}I R_{b s c 1}=A_{b s c 1(t)} / A_{b s c 1(t-1)} * 100, \\
\text { де } A_{b s c 1(t)}-\text { активи групи вітчизняних банків } \\
\text { приватним капіталом банківського сектору країни в } \\
\text { період } t \text {, грн.; } \\
A_{b s c 1(t-1)}-\text { активи групи вітчизняних банків } 3 \text { приватним } \\
\text { капіталом у період } t-1, \text { грн. }\end{array}$ \\
\hline
\end{tabular}




\begin{tabular}{|l|l|}
\hline 9. Індекс розвитку банків & $I R_{b s c 2}=A_{b s c 2(t)} / A_{b s c 2(t-1)} * 100$, \\
iноземних банківських груп & де $A_{b s c 1(t)}-$ активи банків іноземних банківських груп \\
банківського $\quad$ сектору & банківського сектору країни в період $t$, грн.; \\
країни $\left(I R_{b s c 2}\right)$ & $\begin{array}{l}A_{b s c 1(t-1)}-\text { активи банків іноземних банківських груп у } \\
\text { період } t-1, \text { грн. }\end{array}$ \\
\hline
\end{tabular}

3 наведеної в таблиці системи індикаторів, перші два показники використовуються міжнародними фінансовими організаціями в дослідженнях міжнародної банківської діяльності $[10 ; 11]$, інші запропоновані автором. Розрахунками підтверджено доцільність використання показників для оцінювання розвитку банківського сектору в умовах конкурентної інтерналізації (табл. 3).

Таблиия 3

\section{Значення індикаторів оцінки розвитку банківського сектору України в умовах конкурентної інтерналізації}

Table 3

The value of indicators for evaluation of the banking sector development of Ukraine in conditions of competitive internalization

\begin{tabular}{|c|c|c|c|c|}
\hline Показники & $2015 \mathrm{p}$ & $2016 \mathrm{p}$ & $2017 \mathrm{p}$ & $2018 \mathrm{p}$. \\
\hline $\begin{array}{l}\text { 1. Індекс присутності іноземних банків у } \\
\text { банківському секторі країни за їх активами, \% }\end{array}$ & 34,9 & 35,4 & 30,8 & 29,9 \\
\hline $\begin{array}{l}\text { 2. Індекс присутності іноземних банків у } \\
\text { банківському секторі країни за їх кількістю, } \\
\%\end{array}$ & 35,0 & 39,6 & 46,3 & 48,1 \\
\hline $\begin{array}{l}\text { 3. Коефіцієнт конкурентної інтерналізації } \\
\text { (ICI) }\end{array}$ & 0,1225 & 0,1400 & 0,1426 & 0,1440 \\
\hline $\begin{array}{l}\text { 4. Індекс присутності іноземного банку у } \\
\text { банківському секторі країни за його } \\
\text { активами }\end{array}$ & & & & \\
\hline Укрсиббанк & 3,46 & 3,61 & 3,5 & 3,8 \\
\hline Credit Agricole & 1,85 & 2,38 & 2,3 & 2,4 \\
\hline Кредобанк & 0,66 & 0,88 & 1,1 & 1,24 \\
\hline $\begin{array}{l}\text { 5. Розмір сегменту банків з вітчизняним } \\
\text { капіталом у банківському секторі країни } \\
\left(\mathrm{R}_{\mathrm{vbs}}\right)\end{array}$ & 63,5 & 30,7 & 48,1 & 45,9 \\
\hline $\begin{array}{l}\text { 6. Розмір банківського сектору країни по } \\
\text { відношенню до іншої країни }\left(\mathrm{R}_{\mathrm{bsc}}\right) \text {, банку } \\
\text { іншої країни }\left(\mathrm{R}_{\mathrm{bsc}}\right)\end{array}$ & & & & \\
\hline Укрсиббанк & 6791,1 & 3249,3 & 2934,0 & 2288,9 \\
\hline Credit Agricole & 4980,5 & 5000,2 & 4935,9 & 3688,6 \\
\hline Кредобанк & 12497,1 & 11378,3 & 9566,98 & 7030,8 \\
\hline $\begin{array}{l}\text { 7. Індекс розвитку банківського сектору } \\
\text { країни }\left(\mathrm{IR}_{\mathrm{bsc}}\right)\end{array}$ & 0,95 & 1,00 & 1,06 & 1,02 \\
\hline $\begin{array}{l}\text { 8. Індекс розвитку групи вітчизняних банків } \\
\left.\text { банківського сектору країни (IR }{ }_{\text {bsc1 }}\right)\end{array}$ & 5,09 & 4,63 & 1,70 & 0,78 \\
\hline $\begin{array}{l}\text { 9. Індекс розвитку банків іноземних } \\
\text { банківських груп банківського сектору } \\
\text { країни }\left(\mathrm{IR}_{\mathrm{bsc}}\right)\end{array}$ & 1,11 & 0,99 & 1,14 & 0,71 \\
\hline
\end{tabular}

За розрахованими даними, значення коефіцієнта конкурентної інтерналізації 
зростає, отже їі умови стають більш жорсткими. Розмір сегменту вітчизняних банків 3 приватним капіталом у банківському секторі країни має тенденцію до зменшення. Значна різниця в даних за 2015 і 2016 роки пов'язана з націоналізацією Приватбанку. В подальшому капіталізація банків привела до поступового збільшення частки. Крім того, середні активи іноземних банків зменшуються. Ця тенденція співпадає з загально світовою, такою, що відзначається у більшості країн.

За запропонованим показником, а саме індексом присутності іноземного банку у банківському секторі країни за його активами, зроблено розрахунки щодо таких іноземних банків, як Укрсиббанк, Credit Agricole, Кредобанк. Отримані значення індикатора вказують на стійку тенденцію до зростання присутності іноземного капіталу цих банків у банківському секторі України. За цим показником можна оцінити вплив банку іноземної банківської групи на конкуренцію, залежно від значення коефіцієнту. 3 обраних для дослідження банків найбільший вплив на конкуренцію здійснює Укрсиббанк.

За коефіцієнтом конкурентної інтерналізації встановлено положення банківського сектору України в кластері країн Співдружності незалежних держав і Свропейського Союзу. Виходячи зі значення коефіцієнту, за станом впливу іноземних банків банківський сектор України може бути порівняний 3 країн Співдружності незалежних держав 3 банківським сектором Молдови, з країн-членів Свропейського Союзу - з банківським сектором Словенії.

Висновки. Таким чином, удосконалено методичний підхід до оцінювання розвитку банківського сектору в умовах конкурентної інтерналізації. Підхід базується на застосуванні сукупності статичних i динамічних індикаторів, у якості яких запропоновано такі: індекси присутності іноземних банків; коефіцієнт конкурентної інтернаціоналізації; розмір банківського сектору; розмір сегменту банків 3 вітчизняним капіталом; індекс розвитку банківського сектору, групи вітчизняних банків, групи банків з іноземним капіталом. Їх використання в комплексі або як окремі на рік або за певний період надасть можливість формувати інформаційно-статистичний ресурс щодо рівня розвитку банківського сектору, зокрема приймати обгрунтовані рішення щодо інтеграції з фінансовою системою іншої країни або економічних об’єднань країн. Так, умови конкурентної інтерналізації в банківському секторі України можуть бути порівняні з такими в Молдові, Словенії.

1. Дятлова Ю. В. Інтернаціоналізація, інтеграція та інтерналізація в банківському секторі: теоретико-методологічні аспекти в контексті глобальної конкуренції. Держава та регіони. Серія «Економіка та підприємництво». 2018. № 6 (105). С. 145-151.

2. Clarke G., Cull R., Soledad M., Peria M., Sánchez S. Foreign Bank Entry: Experience, Implications for Developing Countries, and Agenda for Further Research. World Bank Research Observer. 2003. Vol. 18. P. 25-40.

3. Claessens S. Competitive Implications of Cross-Border Banking. CrossBorder Banking: Regulatory Challenges / Caprio G., Evanoff D., Kaufman G. (Eds.). New Jersey: World Scientific Publishing, 2006. P. 151182.

4. Chava S., Purnanandam A. The Effect of Banking Crisis on Bank-Dependent Borrowers. Journal of Financial Economics. 2011. Vol. 99. P. 116-135.

5. Levitt T. The Globalization of Markets. Harvard Business Review. 1983. 61 (May/June). P. 92-102.

6. Геєць В. Іноземний капітал у банківській системі України. Дзеркало тижня. № 26 (605). 8-14 липня 2006. URL: http://www.dt.ua/2000/2040/53895. (дата звернення: 10.11.2020р.)

7. Банківська система України: становлення і розвиток в умовах глобалізації економічних процесів: монографія / за ред. О. В. Дзюблюка. Тернопіль: «Вектор», 2012. 462 с.

8. Ефективність та конкурентоспроможність банківської системи України: монографія / Г. Т. Карчева та ін.; за заг. ред. д-ра екон. наук Г. Т. Карчевої. Київ: ДВНЗ «Університет банківської справи», 2016. $279 \mathrm{c}$.

9. Пилипів Н. І., П’ятничук І. Д., Боришкевич І. І. Концептуальні аспекти бізнес-аналітики як 
основи фінансової стійкості банків. Актуальні проблеми розвитку економіки регіону. 2019. Вип. 15. Т.1. С. 95-105.

10. Claessens S., Horen N. Foreign banks: trends, impact and financial stability. IMF Working Paper WP/12/10 (January 2012). URL: https://www.imf.org/external/pubs/ ft/wp/2012/wp1210.pdf. (дата звернення: 10.11.2020р.)

11. Bankers without Borders. Global Financial Development Report 2017/2018. URL: https://openknowledge.worldbank.org/bitstream/handle/10986/28482/9781464811487.pdf. _ (дата звернення: 10.11 .2020 р.)

12. Дятлова Ю. В. Концепція конкурентної інтерналізації в банківському секторі: еволюція теорій $\mathrm{i}$ наукові положення. Проблеми і перспективи економіки та управління. 2019. № 1 (17). С. 219227.

\section{References}

1. Diatlova, Yu. V. "Internationalization, integration and internalization in the banking sector: theoretical and methodological aspects in the context of global competition.”State and regions. Economics and $\begin{array}{lllll}\text { Entrepreneurship } & \text { Series, } & 6 & \text { no. }\end{array}$ pp. 145-151.

2. Clarke, G., Cull, R., Soledad, M., Peria, M., and S. Sánchez "Foreign Bank Entry: Experience, Implications for Developing Countries, and Agenda for Further Research.” World Bank Research Observer, vol. 18, 2003, pp. 25-40.

3. Claessens, S. "Competitive Implications of Cross-Border Banking”. CrossBorder Banking: Regulatory Challenges. New Jersey, World Scientific Publishing, 2006, pp. 151-182.

4. Chava, S., and A. Purnanandam. "The Effect of Banking Crisis on Bank-Dependent Borrowers.”.Journal of Financial Economics, vol. 99, 2011, pp. 116-135.

5. Levitt, T. "The Globalization of Markets.” Harvard Business Review, 61 (May/June), 1983, pp. 92102.

6. Geets, V. "Foreign capital in the banking system of Ukraine." Mirror of the week, no. 26 (605), July 8-14, 2006, www.dt.ua/2000/2040/53895. Accessed 10 Nov. 2020.

7. Dzyublyuk, O V., editor. Banking system of Ukraine: formation and development in the context of globalization of economic processes. Ternopil, "Vector”, 2012.

8. Karcheva, G T., editor. Efficiency and competitiveness of the banking system of Ukraine. Kyiv: SHEI "University of Banking”, 2016. 279 p.

9. Pylypiv N. I., Piatnychuk I. D., and I. I.Boryshkevych "Conceptual aspects of business intelligence as a basis for financial stability of banks”. Current problems of economic development of the region, Is. 15, vol. 1, 2019, pp. 95-105.

10. Claessens S., and N.Horen. "Foreign banks: trends, impact and financial stability". IMF Working Paper WP/12/10 (January 2012), www.imf.org/external/pubs/ft/wp/2012/ wp1210.pdf. Accessed 10 Nov. 2020.

11. Bankers without Borders. "Global Financial Development Report 2017/2018”, openknowledge.worldbank.org/bitstream/handle/10986/28482/9781464811487.pdf. Accessed 10 Nov. 2020.

12. Diatlova, Yu. V. "The concept of competitive internalization in the banking sector: the evolution of theories and scientific positions." Problems and prospects of economics and management, no. 1 (17), 2019, pp. 219-227.

УДК 336.77

doi: 10.15330/apred.1.16.74-83

\section{ДОЦІЛЬНСТЬ РОЗВИТКУ НАЦІОНАЛЬНОГО РИНКУ КРЕДИТНИХ ДЕРИВАТИВІВ}

${ }^{1}$ Підприємець

тел.: 050-888-48-85

e-mail: mkoshevtsova@gmail.com

${ }^{2}$ Прикарпатський національний університет 